\title{
The Economics of Slavery in the Eighteenth-Century Cape Colony: Revising the Nieboer-Domar Hypothesis*
}

\author{
ERIK GREEN \\ Department of Economic History, Lund University \\ Box 7083, 22007 Lund, Sweden \\ E-mail: Erik.Green@ekh.lu.se
}

\begin{abstract}
AвSTRACT: The Nieboer-Domar hypothesis has proved to be a powerful tool for identifying the economic conditions under which slavery was more likely to emerge as a dominant form of labour. It states that in cases of land abundance and labour shortages the use of slavery was likely to become a vital alternative means of increasing production. These conditions have been identified for large parts of pre-colonial and semi-colonial Africa. The Nieboer-Domar hypothesis has been used by a number of historians and economic historians to analyse the role of slavery and bonded labour in Africa. The hypothesis is not, however, uncontested. Scholars have criticized it on both theoretical and empirical grounds. This article discusses the validity of the Nieboer-Domar hypothesis using the eighteenth-century Cape Colony as our point of departure. We show that the hypothesis holds in part, but also that it needs to be modified. First, slavery emerged as an urban phenomenon. Second, the use of slaves increased in parallel with other forms of labour, and the role of slaves can be understood only in relation to a wide range of existing labour contracts. Once established, slavery came to play a significant role in facilitating increased production on the settler farms in the eighteenth century. Capacity for surplus production was the key factor, but why slavery became a major form of labour was partly a consequence of its existence in the urban areas and partly of how it could be combined with other forms of labour.
\end{abstract}

\section{INTRODUCTION}

Slavery is occasionally described as a "peculiar institution", developing in relation to exceptional cultural and social conditions. Yet, and as rightly

\footnotetext{
* An earlier version of this article was presented at the "New Frontiers in African Economic History" workshop at the Graduate Institute in Geneva, IO-I 2 September 20I 2. I am grateful for all the comments received from the participants. I have benefited especially from comments by Gareth Austin, Johan Fourie, and Warren Whatley. The article has also improved significantly as a result of the comments made by three anonymous reviewers for this journal.
} 
highlighted by Engerman, it is wage labour rather than slave labour that is

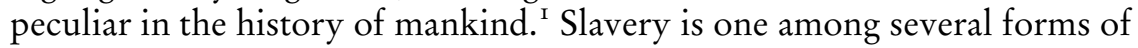
labour emerging from historically specific but not "exceptional" conditions of production and factor markets. The Nieboer-Domar hypothesis ${ }^{2}$ has proved to be a powerful tool for identifying the economic conditions under which slavery was more likely to emerge as a dominant form of labour. The hypothesis states that in cases of land abundance and labour shortages the use of slavery (or bonded labour) became a vital alternative means to increase production. These conditions have been identified for large parts of pre-colonial and semi-colonial Africa. The use of slaves and bonded labour was also widespread. Logically, the Nieboer-Domar hypothesis has also been employed by a number of economic historians and historians to analyse the role of slavery in Africa. The hypothesis is not, however, uncontested. A number of scholars have criticized the hypothesis on both theoretical and empirical grounds. ${ }^{3}$

This article critically discusses the validity of the Nieboer-Domar hypothesis using the eighteenth-century Cape Colony as an empirical point of departure. By doing so, it will also revise previous research on slavery in the Cape and provide an alternative analysis of its trajectory. A lack of reliable data on labour input and land size prevents us from drawing any definite conclusions based on quantifiable data. Instead, the article uses a wide range of different sources, quantitative and qualitative, to unpack the economics of slavery in the Cape (see Figure I).

Focusing on wine and wheat settler farming in the south-western Cape, more specifically the Cape, Stellenbosch, and Drakenstein districts, where the use of slaves was widespread in the eighteenth century, this article considers the extent to which slave use can be explained by the NieboerDomar hypothesis and argues that, though the hypothesis provides a useful starting point, it also needs to be modified. We claim that one must distinguish between the factors leading to the emergence of slavery and those explaining its persistence. The emergence of slavery cannot be traced back to demands from the rural settler sector. Slavery was instead

I. Stanley Engerman, "Slavery and Emancipation in Comparative Perspective: A Look at Some Recent Debates", Journal of Economic History, 46 (1986), pp. 317-339, 318.

2. H.J. Nieboer, Slavery as an Industrial System: Ethnological Researches (The Hague, I900); Evsey D. Domar, "The Causes of Slavery and Serfdom: A Hypothesis", Journal of Economic History, 30 (1945), pp. I 8-32.

3. Bernard J. Siegel, "Some Methodological Considerations for a Comparative Study of Slavery", American Anthropologist, 47 (1945), pp. 357-392; Stanley Engerman, "Some Considerations Relating to Property Rights in Man”, Journal of Economic History, 33 (1973), pp. 43-65; Orlando Patterson, "The Structural Origins of Slavery: A Critique of the Nieboer-Domar Hypothesis from a Comparative Perspective", Annals of the New York Academy of Sciences, 292 (1977), pp. I2-34; Mats Olsson, "Vikingatid träldom - Om slaveriets plats I Skandinaviens ekonomiska bistoria", Lund Papers in Economic History, 67 (1999). 


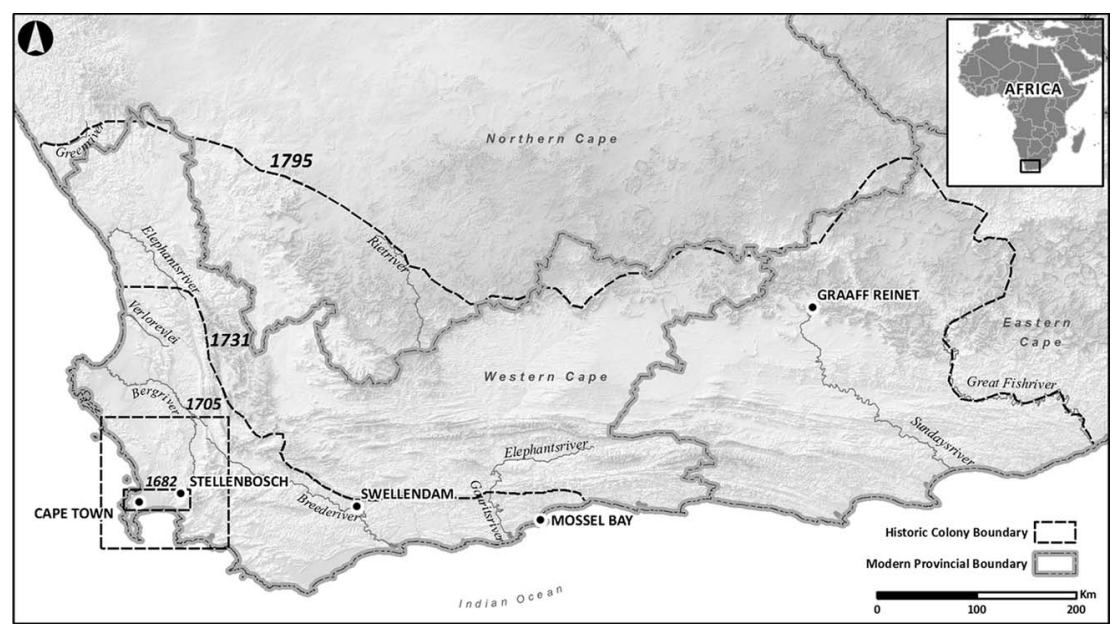

Figure I. The historic boundary of the Cape Colony and modern provincial boundaries of the Western Cape.

Source: Johan Fourie, "The Remarkable Wealth of the Dutch Cape Colony: Measurements from Eighteenth-Century Probate Inventories”, The Economic History Review, 66 (2013), pp. 419-448.

initially an urban phenomenon. Regarding the persistence of slavery, we argue that surplus production must be given a more distinctive role than that offered by the Nieboer-Domar hypothesis. Our findings show that the use of various forms of labour was initially low, but that it increased as the capacity of settlers to expand production rose. We therefore need to analyse the role of slavery in relation to various forms of labour in specific production processes.

In order to allow surplus to play a more distinct role, we argue that one must integrate the modified hypothesis with a conceptual understanding of the production processes. The article shows that a fruitful strategy to link slavery to the production process is to employ Marx's concept of a gap between work and production time and its effect on capital accumulation. His argument has recently been modified by the so-called Mann-Dickinson thesis. ${ }^{4}$ We use the modified thesis to show the circumstances under which slavery helped to spur accumulation. We show that slavery could persist partly because it was possible to combine it with other forms of labour and partly because slaves were leased out as contract labour, i.e. the profitability of slaves alone was not high enough to ensure the survival of the system. 
This article relies on secondary sources and primary sources compiled by numerous colleagues. We have benefited especially from the data compiled by Johan Fourie and his colleagues at Stellenbosch University. We have benefited equally from the data used by Nigel Worden and published in his Slavery in Dutch South Africa, as well as works by Johan Fourie and his co-authors.'

The data available for the Cape Colony are impressive compared with those for other slave societies. However, there are a number of factors for which data do not exist. First, we lack accurate information on land size. Second, we know a reasonable amount about the large slave owners but less about those who held a small number of slaves. This means that the role and profitability of slaves might be exaggerated. Third, and related to the second limitation, very little has been written about the role of indigenous labour on the wheat and wine farms, although there are important studies of the relationship between indigenous peoples and settler colonists (see below). We do not know how many of them worked on the wine and wheat farms or how much they were paid. This has consequences for our understanding of slavery in the Cape, as the invisibility of the indigenous people might distort the calculations of the productivity and profitability of slave labour.

\section{THE NIEBOER-DOMAR HYPOTHESIS AND SLAVERY IN AFRICA}

Unlike slavery on the plantation complexes in the New World, slavery in Africa grew piecemeal and varied significantly both between and within societies. This has led scholars to claim that the causes and effects of slavery in Africa lay in different political, cultural, and social factors. In a classic article, Miers and Kopytoff argue, for example, that the roots of slavery in Africa "must be sought in the total social and political economy of a society". "However, a number of economic historians have claimed that slavery in Africa is best understood as an economic institution, emerging as a response to the will to expand production in contexts of labour scarcity, a hypothesis initially formulated by the Dutch ethnologist H.J. Nieboer.?

5. Nigel Worden, Slavery in Dutch South Africa (Cambridge, 1985), and, for example, Johan Fourie and Dieter von Fintel, "The Dynamics of Inequality in a Newly Settled, Pre-industrial Society: The Case of the Cape Colony", Cliometrica, 4 (2010), pp. 229-267; W.H. Boshoff and J. Fourie, "The Significance of the Cape Trade Route to Economic Activity in the Cape Colony: A Medium-Term Business Cycle Analysis”, European Review of Economic History, I 4 (2010), pp. 469-503.

6. S. Miers and I. Kopytoff, "Introduction", in idem (eds), Slavery in Africa: Historical and Anthropological Perspectives (London, 1977), p. 69.

7. A.G. Hopkins, An Economic History of West Africa (London, 1973); David Northrup, "Nineteenth-Century Patterns of Slavery and Economic Growth in Southeastern Nigeria", 
Based on a large number of ethnographic studies from America, Asia, and Africa, Nieboer argues that slavery would not exist if it had no economic value. To account for the latter, Nieboer distinguishes between economies with open and closed resources. In an agricultural economy with closed resources, all land has been appropriated, which prevents the opening of new farms, leading to a class of landless people who own nothing but their labour. In such a context slavery might exist, but not, in Nieboer's terms, as an industrial system (i.e. economic system). In an open resources economy, on the other hand, land is available in abundance. Under such circumstances the incentives for a person to sell his or her labour power are greatly reduced. Expanding production under such conditions requires landlords to employ coercive measures, i.e. to rely on bonded labour or slavery. ${ }^{8}$

Nieboer's hypothesis is not deterministic, i.e. he denies that a universal correlation exists between land-labour ratios and slavery. The extent to which slavery would be employed under conditions of labour scarcity depended on the incentives to increase production and the possibility of substituting wage labour with forms of labour other than slavery. Nieboer mentions a number of possible substitutes, including exploiting female labour or accessing labour through kinship ties. ${ }^{9}$

Nieboer's contribution was largely ignored by economic historians until Domar published "The Causes of Slavery and Serfdom" in 1970. Domar accepts the basic premises of Nieboer's hypothesis but argues that it needs to be modified. Domar claims that the logical outcome in an economy with open resources - assuming that land and labour are the only factors of production, that the land is of uniform quality, that there are no diminishing returns of labour, and that the average and marginal productivity of labour are constant - would be the development of an economy based on family farming, as no land rents would arise in such a system. ${ }^{10}$

Relaxing the assumption of uniform land quality and equal access to capital would not alter the outcome, as long as we assume that skills could be acquired relatively easily. The capital needed to start a farm is small and the average income relatively high due to land surplus. Under such conditions, the economy would still consist mainly of family farms with a

International Journal of African Historical Studies, I 2 (1979), pp. I-I6; Gareth Austin, Labour, Land, and Capital in Ghana: From Slavery to Free Labour in Asante, 1807-1956 (Rochester, NY, 2005); idem, "Factor Markets in Nieboer Conditions: Pre-Colonial West Africa, c.I 500-c.1 900", Continuity and Change, 24 (2009), pp. 23-53; Charles H. Feinstein, An Economic History of South Africa: Conquest, Discrimination and Development (Cambridge, 2005).

8. Nieboer, Slavery as an Industrial System, pp. 420-42 I.

9. Ibid., p. 427.

ı. Domar, "The Causes of Slavery", pp. 19-20. 
small estate sector that operates on the best land and employs wage labour. ${ }^{\mathrm{II}}$ This leads Domar to conclude that the presence of free land is neither necessary nor sufficient to explain slavery. Domar writes that the model "cannot predict the net effect of a change in the land/labour ratio on the position of the peasants". ${ }^{2}$ The effect is determined by politics. For example, a class of workers and/or tenants can develop in contexts of land abundance if the landlord is able to prevent mobility and restrict rights to land. ${ }^{13}$

The Nieboer-Domar hypothesis is not uncontested. The anthropologist Bernard Siegel claims the hypothesis is monistic and neglects the role of social and cultural factors. ${ }^{14}$ In a similar vein, Orlando Patterson criticizes the hypothesis for being "vulgar economic determinism". Is Patterson uses Murdock's Ethnographic Atlas to test empirically the relationship between land-labour ratios and slavery in different societies. ${ }^{16} \mathrm{He}$ argues that the cross-sectional analysis reveals that the relationship between population densities and slavery is curvilinear. For some societies it is positive and for others, including both pastoral and agricultural societies, negative. The variable that seems to matter is surplus production, which affects the relationship in different ways depending on the degree to which a society is dependent on agriculture, but in no case is the relationship between population and slavery linear. ${ }^{17}$

That surplus matters is not inconsistent with the Nieboer-Domar hypothesis. Both Nieboer and Domar argue that the thesis applies only in contexts in which farmers have a capacity to generate surplus production. More important therefore is Patterson's finding of a curvilinear relationship between population densities and slavery. He uses the case of Greece (from the 8th to the sth century BC) as an in-depth study to strengthen his argument, and shows how cultural factors played a far more important role than economic ones. More specifically, he argues that it was Greek attitudes to manual labour that played a decisive role in the

I I. Ibid., p. 20.

I2. Ibid., p. $2 \mathrm{I}$.

I3. Ibid.

I4. Siegel, "Some Methodological Considerations", pp. 357-362.

i s. Patterson, "The Structural Origins of Slavery", p. 30.

16. The Atlas allows for a cross-sectional comparison but not for the study of change over time. Patterson solves this problem by analysing the cross-sectional findings with a historical in-depth case - Greece from the 8th to the sth century BC. It should be noted that the Atlas has been heavily criticized by anthropologists and historians alike, though it is still used by a number of economists. See Jutta Bolt, "Quantifying Pre-Colonial Institutions in Africa: Assessing the Reliability of the Ethnographic Atlas", paper presented at the Conference on "The New Institutional Economics and Divergence in the Developing World", Lund, 27-28 September 20I2, for a review of the critique.

I7. Patterson, "The Structural Origins of Slavery", p. 25. 
development of slavery. Peasants refused to take up manual labour even in times of high population densities and land scarcity, leaving landowners with no alternative than to employ slaves. ${ }^{18}$

Engerman, who, like Nieboer and Domar, defines slavery as an economic institution, is sympathetic to the hypothesis in general and Domar's extended model in particular. However, like Patterson, he underlines the importance of surplus production and political institutions. ${ }^{19}$ Engerman shows that in Domar's extended model slavery is still only one among several alternatives. ${ }^{20}$ Serfdom and the imposition of a "tax state" or a cartel among the users of labour are equally valid options. ${ }^{21}$ Engerman argues that we need to separate the factors that lead to the emergence of slavery and those that enable the system to persist. $\mathrm{He}$ claims that once slavery has been established there are strong incentives to ensure that the system is maintained in order to prevent capital losses for the slaveholders. ${ }^{22}$ While supplies of labour may matter for the emergence of the system, they matter less for its persistence.

How well does the hypothesis then travel to the African cases? A seminal contribution to the debate is A.G. Hopkins's work on the economic history of West Africa. Hopkins was directly inspired by Nieboer's work. He argues, referring to the factor endowments in pre-colonial West Africa, that "[s]laves were preferred because the costs of acquiring and maintaining them were less than the cost of hiring labour". ${ }^{23}$ In a similar vein, by studying three different societies in pre-colonial south-eastern Nigeria, Northrup concludes that factor endowments explain variations in the use of slaves. ${ }^{24}$ In a more recent contribution, Austin discusses the validity of the NieboerDomar hypothesis in the case of nineteenth-century Asante. Inspired by the critique of the hypothesis, he discusses alternative strategies to meet labour scarcity, but concludes that "[i]n terms of self-interest it benefitted chiefs and free subjects to join together in the exploitation of outsiders". ${ }^{25}$

Both Hopkins and Austin stress that the Nieboer-Domar hypothesis should not be understood as an economic-deterministic explanation. Hopkins, for example, claims in a footnote that slavery could exist without labour shortages and that shortages of labour do not always lead to enslavement. ${ }^{26}$ He concludes, however, that in the case of pre-colonial West Africa the

I8. Ibid., p. 3 I.

19. Engerman, "Some Considerations Relating to Property Rights", p. 58.

20. Ibid., pp. 56-57.

21. Ibid., p. 58.

22. Ibid., p. 60.

23. Hopkins, Economic History of West Africa, p. 25.

24. Northrup, "Nineteenth-Century Patterns of Slavery", p. I6.

25. Austin, Labour, Land, and Capital in Ghana, p. I58.

26. Hopkins, Economic History of West Africa, p. 24. 
more orthodox version of the Nieboer hypothesis applied. Austin, on the other hand, argues that the hypothesis applied only as long as the kingdom held a local monopoly of the most valuable of natural resources, i.e. the forest, and as long as the analysis does not extend beyond the slaveimporting economy to include those areas from which the captives came. ${ }^{27}$ Given this, he concludes that material obstacles existed to obtaining labour without the use of coercion, and he thus states that the Nieboer-Domar hypothesis holds in the case of Asante. In a recent review of factor markets in pre-colonial West Africa he concludes that "in economic terms there could have been no labour market without coercion". ${ }^{28}$

In the case of the Cape Colony, there are a number of scholars who indirectly rely on the Nieboer-Domar hypothesis by pointing out the lack of alternative sources of labour. ${ }^{29}$ To date, Feinstein and Shell are the only scholars, to our knowledge, who explicitly acknowledge Nieboer's and Domar's work. Feinstein argues that factor endowments in the eighteenthand nineteenth-century Cape were characterized by an abundance of land and shortages of labour. He concludes that under these conditions settler farmers "did resort to slavery and other systems of coercion in order to ensure a supply of labour"..$^{\circ}$ Feinstein's contribution is appreciated and important. However, he does not provide a detailed case study, or take the critique of the original and extended hypothesis into account. Shell seems to have reached a similar conclusion ten years earlier. In line with Domar, he stresses the importance of political and/or economic groups powerful enough to initiate slavery. He states that "Since available land and a group of powerful persons were present in early South Africa, we should not be surprised that Domar's predicted result - slavery and serfdom - also quickly came about." ${ }^{\text {I }}$ Yet the economics of slavery are presented as a stylized fact rather than being discussed in relation to the empirical information available. It therefore becomes difficult to accept Feinstein and Shell's conclusion uncritically.

In line with Engerman, ${ }^{32}$ we argue that one must separate the factors that explain the rise of slavery from those that account for its persistence. Slavery did not emerge in response to demands from settler farmers. It was the Dutch East India Company, the VOC (Verenigde Oostindische Compagnie), which controlled the colony and needed the slaves, and from

27. Austin, Labour, Land, and Capital in Ghana, p. 170.

28. Idem, "Factor Markets in Nieboer Conditions", p. 25. Note that Austin differs from Hopkins in arguing that farmers did not face a choice. Labour could not be allocated without the use of coercive measures.

29. Worden, Slavery in Dutch South Africa; Fourie and Von Fintel, "Dynamics of Inequality". 30. Feinstein, Economic History of South Africa, p. 33 ; Robert C.H. Shell, Children of Bondage: A Social History of the Slave Society at the Cape of Good Hope, 1652-I 838 (London, 1994).

3. Shell, Children of Bondage, p. 2.

32. Engerman, "Some Considerations Relating to Property Rights". 
the very beginning slavery was largely an urban phenomenon, i.e. the institution existed in the Cape before the settler farmers were able to produce a sustainable surplus. The demand for slave labour on the farms began to increase once settlers had reached the capacity to generate sustained surplus production. In line with Domar and Engerman, we thus argue that the capacity to produce a surplus played a crucial role in the spread and persistence of slavery in the Cape. So far, our argument is consistent with the Nieboer-Domar hypothesis. However, our findings indicate that it was not only the demand for slavery that increased with the increased capacity to produce a surplus. Demand for various forms of labour, including indigenous labour, increased alongside slavery. The growth process also created its own labour contracts, as large slaveholders began to hire out slaves as contract labourers to other settler farmers. The role and profitability of slavery can thus be understood only in relation to the use of a wide range of labour arrangements in the specific production processes.

We suggest that a fruitful starting point for identifying the role of slavery in the production process is a basic premise from Marx's writings, namely that the periods in which labour is not used in the production process create neither value nor surplus value. Thus, the more often production time and labour time coincide, the greater the productivity and accumulation of capital. This has been used by Mann and Dickinson to explain the slow expansion of capitalist relations of production. ${ }^{33}$ The thesis presumes that wage labour by definition is the optimal choice due to its higher productivity. Mann writes that "non-wage forms of production continue to exist, not because they are preferred avenues of capital accumulation, but because they are unavoidable features of the modern landscape". ${ }^{34}$ This is, as Banaji reminds us, to reduce Marx's concept of mode of production to simple abstractions. ${ }^{35}$ We argue that the preferred choice of labour is historically conditioned, while the relative efficiency of labour in terms of creating surplus value is determined by a generic factor, namely the gap between work and production time.

\section{SLAVE LABOUR IN THE EIGHTEENTH-CENTURY CAPE: A MODIFICATION}

The Cape was settled in 1652 by the VOC as a refreshment station for passing ships. The first commander of the station, Jan van Riebeeck, soon reported back to the directors of the VOC that he needed more

33. Mann and Dickinson, "Obstacles”; Mann, Agrarian Capitalism.

34. Mann, Agrarian Capitalism, p. 33.

35. Marx implicitly distinguishes between simple and true abstractions. The former refer to ahistorical generalizations, while the latter are historically conditioned. See J. Banaji, Theory as History: Essays on Modes of Production and Exploitation (Chicago, IL, 2010), p. 53. 
Europeans to settle in the Cape as free farmers in order to ensure sufficient production of food. Initially, he gave a few company officials land, but they lacked both capital and labour to cultivate it effectively. By I663 there were only I6 settlers in the Cape, far less than the I,000 that Van Riebeeck had hoped for. ${ }^{36}$ It was not until the late seventeenth century that the settlement began to expand and a small but dispersed free settler society was established, supplying the fort primarily with wheat, wine, and cattle. In the eighteenth century wine and wheat farming came to dominate economic activity in the south and south-western Cape. In the interior, where low levels of rainfall prevented the growth of arable agriculture, settlement was both sparse and dispersed, and farmers concentrated mainly on pastoral farming. ${ }^{37}$

For a long time, the Cape was described as having been an impoverished and destitute settlement. However, by the late I980s this view had been challenged by Van Duin and Ross. Using the tax returns (opgaaf) obtained from the Dutch archives, the authors argued that the Cape had a fairly competitive economy, which experienced significant growth in the eighteenth century. Unlike earlier accounts, that partly explained the stagnant economy in terms of low levels of export and relatively fewer passing ships, Van Duin and Ross emphasized the role of local demand as a driving force of economic growth. ${ }^{3}$ In a more recent article, Boshoff and Fourie share the more positive view of the Cape Colony, but argue that exports, at least wheat exports, played a significant role in growth. The increased commercialization of settler farming helped to produce a prosperous agrarian elite (the Cape gentry), although it did not lead to a monocultural plantation system supplying the metropolitan market, as was the case with West Indian sugar and Brazilian coffee. ${ }^{39}$ The settlers were thus a fairly heterogeneous group by the mid-eighteenth century, including absentee landlords who lived in Cape Town, resident landlords who were tied to production for the Cape Town market, and members of an "industrious class" who worked side by side with their labourers. ${ }^{40}$ The level and dynamics of inequality are important since they affect our understanding of slavery in the Cape, as will be discussed further below.

36. Fourie and Von Fintel, "Dynamics of Inequality", p. 234.

37. J.E. Mason, Social Death and Resurrection: Slavery and Emancipation in South Africa (Charlottesville, VA, 2003), p. I6.

38. P. van Duin and R. Ross, The Economy of the Cape Colony in the Eighteenth Century (Leiden, 1987). For a brief overview see Boshoff and Fourie, "Significance of the Cape Trade", pp. 469-503.

39. Worden, Slavery in Dutch South Africa, p. I9.

40. W. Dooling, "The Making of a Colonial Elite: Property, Family and Landed Stability in the Cape Colony, c.1750-1834”, Journal of Southern African Studies, 31 (2005), pp. I47-162. 


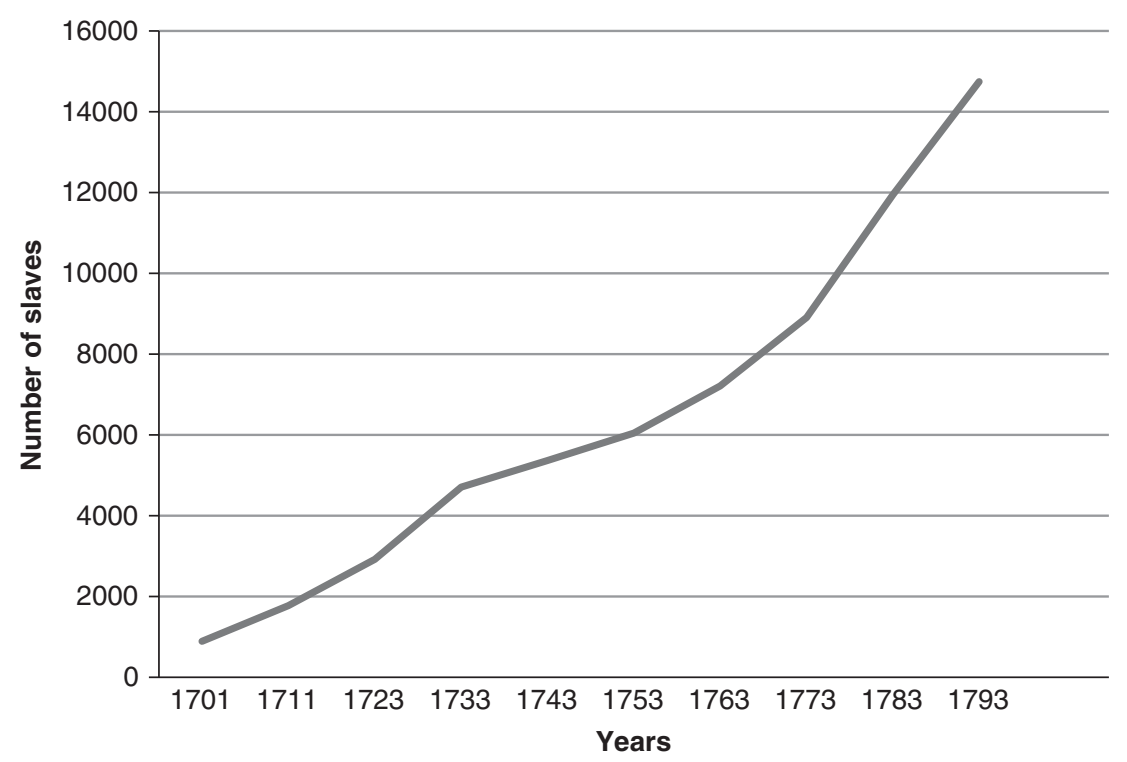

Figure 2. Number of slaves in the Cape Colony, 1692-1793.

Source: Worden, Slavery in Dutch South Africa, p. I I.

Figure 2 shows that the number of slaves imported increased steadily throughout the eighteenth century. Unlike plantation societies in the United States and the Caribbean, slaveholding in the Cape was widespread and even poorer settlers in the interior often held slaves. ${ }^{4 \mathrm{I}}$ Indeed, by I 800 approximately 90 per cent of all settler farmers in the Cape owned slaves..$^{42}$ Armstrong and Worden ${ }^{43}$ suggest a strong positive correlation between slave ownership and yields of wine and wheat. This view is confirmed by earlier observers. Mentzel, a visitor to the Cape, stated in the I730s that "the expansion of the colony demands an ever increasing number of slaves. Every farmer requires many more slaves than members of his own household to grow his crops and develop his land." 44 Although the ratio of slaves to free men was far lower than in the plantation complexes in the British West Indies or the Zanzibar clove plantations, the Cape figure was similar to that of several other notable slave societies, including the Roman Empire. ${ }^{45}$

4I. Fourie and Von Fintel, "Dynamics of Inequality", p. 4.

42. Mason, Social Death and Resurrection, p. 25.

43. J.C. Armstrong and N. Worden, "The Slaves, 1652-1834", in R. Elphick and H. Giliomee (eds), The Shaping of South African Society, I652-I840 (Middletown, CT, I988).

44. Quoted in Worden, Slavery in Dutch South Africa, p. Io.

45. Ibid., pp. Iо-I I. 
There is scattered, but on the whole convincing, evidence indicating that the role of slaves might be exaggerated. First, the average number of slaves per farm was relatively low. By the mid-eighteenth century more than 50 per cent of farmers held fewer than five slaves, and in 177424 per cent of settlers had no slaves at all. This could be compared with the "median sugar estate" in Jamaica, which between I74I and I745 held an average of 99 slaves, increasing to 204 for the years 177 I to $1775 .{ }^{46}$ Secondly, the role of indigenous labour seems to have been systematically underestimated in previous research. The indigenous people in the Cape are often referred to as Khoikhoi and San (known by the Dutch as Bushmen and Hottentot).

One must stress that anthropological research has made it clear that the two groups are not discrete racial categories. The Dutch did not distinguish between the Khoikhoi and San in physical terms, rather as different socioeconomic systems. San were believed to be gatherers and hunters, while the Khoikhoi were pastoralists. Based on this distinction the Dutch widely discussed matters related to the Khoikhoi but seldom those relating to the San. The occupational distinction is also problematic. People recognized as belonging to the Khoikhoi could be cattle-less, just as the San could be cattle holders. ${ }^{47}$ In this article, indigenous people are thus referred to as Khoisan, as a generic term for the indigenous population, although we acknowledge the fact that the Khoisan were not a homogenous group of people.

Having said that, Guelke and Shell rightly concluded that "[a]lthough scholars have noted the participation of Khoikhoi in Cape agriculture, the extent and economic value of that participation need to be fully appreciated". ${ }^{8}$ In 1695 Johannes Willem de Grevenbock referred to Khoikhoi labour in rather enthusiastic terms: ${ }^{49}$

They train oxen for use in ploughing [...] and are found exceedingly quick at inspanning or outspanning or guiding teams. Some of them are very accomplished riders, and have learned to break horses and master them [...]. They make trusty bearers, porters, carriers, postboys and couriers. They chop wood, mind the fire, work in the kitchen, prune vines, gather grapes, or work the wine press industriously $[\ldots]$. Without relaxation they plough, sow, and harrow. ${ }^{5 \circ}$

46. Johan Fourie, "Slaves as Capital Investment in the Dutch Cape Colony, I652-1795", Stellenbosch Working Papers 21/2011, p. 6.

47. Shula Marks, "Khoisan Resistance to the Dutch in the Seventeenth and Eighteenth Centuries", Journal of African History, I3 (1972), pp. 55-80, 57-58.

48. Leonard Guelke and Robert Shell, "An Early Colonial Landed Gentry: Land and Wealth in the Cape Colony I682-173 I", Journal of Historical Geography, 9 (1983), pp. $265-286,276$.

49. This enthusiasm was not shared by everyone. Sailors in the early colonial period commonly referred to the Khoi as "black stinking dogs"; Hermann Giliomee and Richard Elphick, "The Structure of European Domination at the Cape, I652-1820", in Elphick and Giliomee, Shaping of South African Society, pp. 359-390, 362.

50. Cited in R. Elphick and V.C. Malherbe, "The Khoisan to I 828 ", in Elphick and Giliomee, Shaping of South African Society, p. I7. 
The quotation reveals that the Khoisan labourers were employed for a wide range of tasks and that they were able to move up the social ladder and become supervisors of working gangs. Guelke and Shell write that in I688 the Khoikhoi were so prominent and appreciated that the Cape Commander Simon van der Stel concluded that it resembled the descent of migrant workers from Westphalia upon the Netherlands. ${ }^{51}$ However, the two statements above refer to the situation in the late seventeenthcentury Cape when the use of slavery had not yet taken off.

There is, however, evidence that indicates that Khoisan labour continued to play an important role throughout the eighteenth century. In I706 it was reported that Khoisan moved in gangs from farm to farm in search of temporary wage employment. ${ }^{52}$ Further, Guelke estimates that by 1780 a total of about 20,000 Khoikhoi and 3,000 San still lived in the Cape, accounting for about one-half of the total population of the Cape. ${ }^{53}$ Stripped of land, the Khoisan were left with few alternatives other than to seek employment among the Europeans. The first census that included Khoisan labourers dates from I806. It reveals that Khoisan labourers accounted for about 30 per cent of the total labour force in the Stellenbosch and Drakenstein districts of the south-western Cape. The census also indicates, not at all surprisingly, that a majority of farmers used both Khoisan labourers and slaves ( 54.2 per cent). ${ }^{54}$ (Figure 3)

Furthermore, the farmers often complained that the VOC employed a huge number of Khoisan labourers, leading to shortages in supplies of farm labourers. 55 Wheat farmers on large landholdings were complaining as early as 1744 that they were being forced to limit the size of their crops because of shortages in the supply of Khoisan labour. ${ }^{56}$ It is thus far from clear how the sources should be interpreted, though it seems fairly plausible to conclude that Khoisan labour played a significant role, which we must take into consideration when we discuss slavery and the Nieboer-Domar hypothesis. In order to gain a proper understanding of slavery, we must therefore acknowledge that it is unlikely that the majority of farmers could have managed by relying only on the slaves they owned.

51. Leonard Guelke and Robert Shell, "Landscape of Conquest: Frontier Water Alienation and Khoikhoi Strategies of Survival, I652-1780", Journal of Southern African Studies, I 8 (1992), p. 8 I 2 .

52. Shell, Children of Bondage, p. 27.

53. Worden, Slavery in Dutch South Africa, p. I I.

54. Ibid., p. 35. Worden argues that these figures might indicate a higher percentage use of Khoisan labourers than was normal for the eighteenth century because of increased shortages of slave labour in the late eighteenth century. On the other hand, one might expect farmers to have underreported the number of day labourers employed as part of a strategy to avoid taxes (we know that farmers tended to underreport the size of their farms); see ibid., p. 24.

55. Ibid., p. 36.

56. Ibid., p. 33 . 


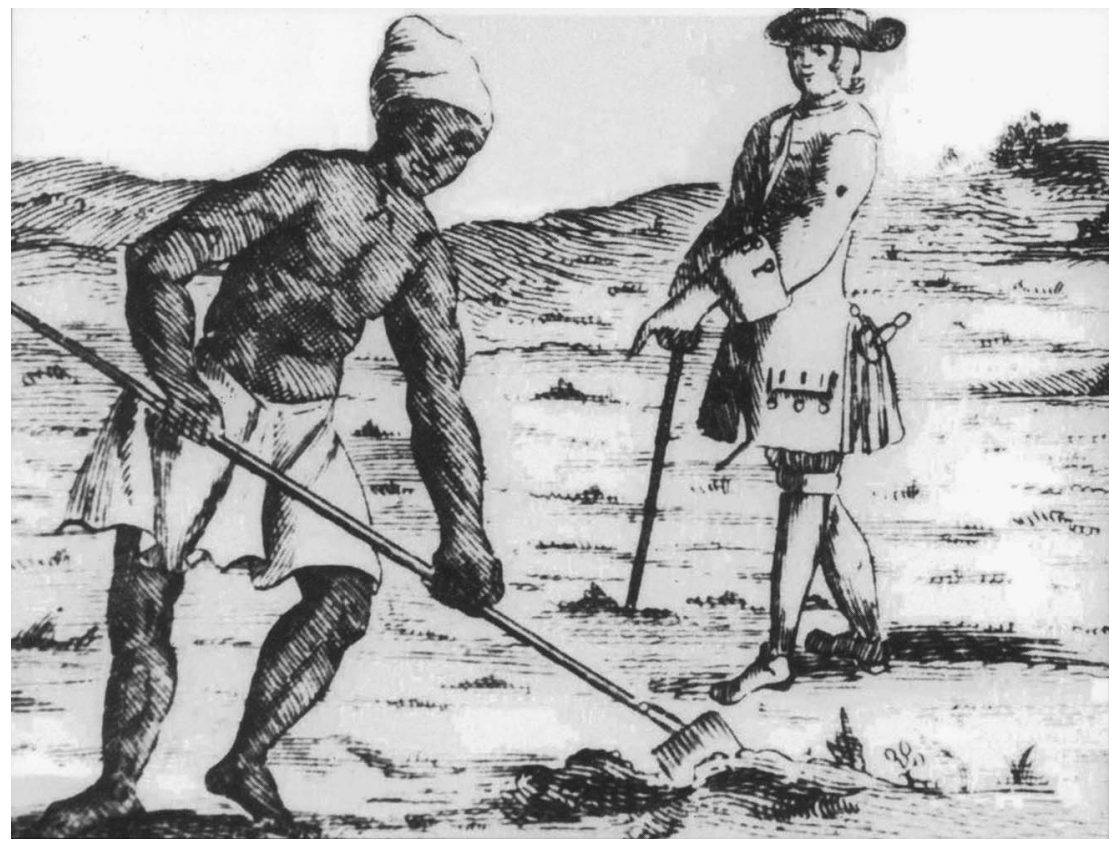

Figure 3. The Khoisan played a significant role as farm labourers throughout the eighteenth century. They were employed for all sorts of tasks, from herding to harvesting. The picture shows a male Khoisan (name unknown) hoeing under the supervision of his Master.

Source: Peter Kolb, Caput Bonae Spei Hodiernum (Nuremberg, 1719), in Nigel Worden and Gerald Groenewald (eds), Trials of Slavery (Cape Town, 2005).

\section{LABOUR IN THE EARLY COLONIAL PERIOD}

Importing African slaves was not the first option considered by the VOC. Initially the VOC suggested that the demand for labour could be met by the immigration from Europe of men who could be employed as indentured labourers. The idea of enslaving the indigenous people was not considered, as Dutch law had forbidden the enslavement of local populations. ${ }^{57}$ Immigrants did come to the Cape, but in small numbers during the first two decades of the Company's rule. The next best alternative would be to find labourers elsewhere who could be employed as wage workers. Van Riebeeck suggested using Chinese immigrants, as in Batavia, but plans were abandoned owing to the cost of their passage. Instead, slaves from Africa seemed to be the most reliable alternative. Slaves from West Africa could be bought with the help of the Dutch West India Company, while the Company's contacts with Asian slave traders helped 
them obtain slave labourers in the east. Initially, the Company offered slaves on credit to burghers in order to stimulate production, and after some initial difficulties the number of slaves began to rise steadily in the 1680 s. $^{58}$

As mentioned earlier, a number of scholars argue, in line with the official view of the VOC, that slavery in the Cape developed because of the lack of alternatives. The question is to what extent this is a plausible argument, and if it is, to what extent it was an effect of land-labour ratios. Following the Nieboer-Domar hypothesis, we must try to establish the demography of the indigenous people in the region. We lack completely reliable figures, but Richard Elphick, the expert in the field, argues that on the arrival of the VOC about 50,000 Khoisan lived in an area covering roughly I29,462 square kilometres, which gives a population density of 0.39 people per square kilometre. ${ }^{59}$ According to Ross, the Khoisan depended solely on hunting and cattle herding. The only crop the Khoisan were recorded as having grown was dagga (cannabis). The material basis of Khoisan society prevented high population growth. ${ }^{60}$

The high land-labour ratios indicate that labour was scarce, i.e. the Nieboer-Domar hypothesis seems to apply in the Cape case. However, we also need to know how European expansion in the early colonial period affected Khoisan access to land in order to obtain a more reliable account of the supply of indigenous labour. Unfortunately, there is no detailed information on the total size of European landholdings or detailed accounts of how European control over land expanded from I650 to 1680 . However, by using scattered evidence from previous research we can establish a fairly reliable picture of European expansion.

In the very early years the expansion was modest. The few farmers who arrived at the Cape settled down in the immediate surroundings of Cape Town and it appears that the European intruders and the indigenous people lived side by side without any major conflict. Europeans were too few too to threaten seriously the access of indigenous people to land. ${ }^{6 r}$ However, the number of settlers continued to increase and by 1690 European settlers controlled almost all the land in the south-western Cape, though only a small proportion of it was actually cultivated. The limited capacity of Europeans to exploit the resources they controlled enabled the indigenous people to continue to use the land that they no longer had a "legal" right to. Guelke and Shell write, with reference to the

58. Worden, Slavery in Dutch South Africa, pp. 7-9.

59. Richard Elphick, "The Khoisan to c.1770", in Elphick and Giliomee, Shaping of South African Society, pp. 3-4. Sadly, he does not present any figures for the San people.

60. Robert Ross, "Ethnic Identity, Demographic Crisis and Xhosa-Khoikhoi Interaction", History in Africa, 7 (1980), pp. 259-271, 265.

61. Guelke and Shell, "Landscape of Conquest", pp. 803-824, 804-808. 
Stellenbosch district in I687, that "the settlers had gained effective control of the Stellenbosch District, but they continued to share its pasture lands with the Khoikhoi, who were still present in considerable numbers and lived independently in their own settlements". ${ }^{62}$

This leads us to conclude that even though the indigenous people had been stripped of their land, it did not, initially, threaten their socioeconomic organization. On the contrary, as many scholars have pointed out, their social organization remained intact in the early years of the colony. ${ }^{63}$ Worden claims that:

There were major impediments to using indigenous labour as hired labourers or as slaves. There were no means at first of enforcing Khoikhoi to work for the colonist farmers without enslavement; they had an abundance of grazing land and cattle, an intact social organization, and could have easily evaded attempts at coercion by the Company and settlers by moving further inland. ${ }^{64}$

Meanwhile, it was in the interests of the VOC to maintain amicable relations with the Khoisan, partly because they wanted to ensure a continuation of the cattle trade and partly because they were in need of collaborators, i.e. middlemen, mediators, and interpreters. ${ }^{65}$ From the very start, the Khoisan had shown a reluctance to trade with the Dutch intruders. Marks claims that one reason that the VOC decided to allow Europeans to open up farms was the Company's inability to develop strong trading ties with the indigenous population. ${ }^{66}$

One should thus be careful about describing the early colonial period in terms of cooperation between the intruders and the indigenous people. Tension, social conflict, and even minor warfare were common between the Khoisan and the Dutch in the seventeenth and eighteenth centuries. In I659 the first of two seventeenth-century wars broke out. The Khoi stole ploughoxen and conducted guerrilla warfare on rainy days when Dutch muskets could not fire. The strategy was partly successful as almost one-half of the Company servants and burghers tried to escape by stowing away on passing vessels. ${ }^{67}$ However, the Khoisan were not a homogenous group. As one group became impoverished or reluctant to trade another would take its place. ${ }^{68}$ Stratification within the groups was also notable. Previous research has shown that the chiefs in Khoisan societies belonged to the economic elite, cattle traders, and that they had a lot to gain by trading with the Dutch. ${ }^{69}$

\author{
62. Ibid., p. 8 I 3 . \\ 63. Worden, Slavery in Dutch South Africa, p. 7. \\ 64. Ibid. \\ 65. Marks, "Khoisan Resistance to the Dutch", pp. 60-63. \\ 66. Ibid., p. 63. \\ 67. Ibid., p. 64. \\ 68. Ibid., p. 66. \\ 69. Ross, "Ethnic Identity, Demographic Crisis", p. 265.
}


The stratification between and within groups managed to ensure that the scattered but significant Khoisan resistance never developed into full-scale war. On the contrary, though resistance never ceased it became more sporadic and less well-organized..$^{\circ}$

Our pragmatic conclusion is that both high land-labour ratios and the interdependence between parts of the Khoisan and the Company elites kept the supply of labour low, and it thus seems that the Nieboer-Domar hypothesis provides a valid explanation for the early colonial period.

Meanwhile, the use of slavery was minimal during that period. By I 677 there were 106 slaves ( $8 \mathrm{I}$ male and 25 female) owned by white farmers. The figure can be compared with the 1682 population census, which identified 288 white settlers living in the Cape. Of these, 89 were men. ${ }^{7 \mathrm{I}}$ Unfortunately we have no information on landholding sizes. We know that settlers were granted 60 morgen (about 50 hectares) per farm. Some might have had larger farms, while a few smaller landholdings had been divided due to the Dutch system of inheritance. ${ }^{72}$ If we assume that each male had one farm of approximately 50 hectares, we obtain a ratio of about I.2 slaves per farm. It is likely that the slaves were unevenly distributed among the settlers. Either way, the majority of farmers did not depend on slaves as a chief source of labour.

According to Worden, the settlers who had settled in the Cape during the first few decades of the Dutch colony relied instead on local labour employed as serfs, local wage labour, and indentured VOC servants (knechts). ${ }^{73}$ The limited supply of labour did not pose a threat for the European farmers as their demand for labour was equally low. The number of settler farmers was small, as shown above, and in the first few decades of the colony's existence farming was far from being a success story. Harvest failures and food shortages were fairly common, and the VOC often had to turn to the Netherlands for support. ${ }^{74}$ Living conditions for the few settlers in the Cape were also poor. The Church often collected money to give to the needy, and "naked kids were sleeping in the

70. Marks, "Khoisan Resistance to the Dutch", p. 68.

7I. Leonard Guelke, "The Anatomy of a Colonial Settler Population: Cape Colony 1657-1750", International Journal of African Historical Studies, 2 I (1988), pp. 453-473, $459-460$.

72. The system implied that, regardless of its sex, each child was statutorily entitled to an equal share of land. The inheritance shares could be altered in a will, but no spouse or child could be denied more than half of his or her statutory share; Leonard Guelke, "The White Settlers, 1652-1780", in Elphick and Giliomee, Shaping of South African Society, p. 57.

73. Worden, Slavery in Dutch South Africa, p. 7; see also Giliomee and Elphick, "The Structure of European Domination", in Elphick and Giliomee, Shaping of South African Society, pp. 359-390.

74. Fourie and Von Fintel, "Dynamics of Inequality", p. 234. 
hay with horses and cattle". ${ }^{75}$ Alternatively, one could argue that the low supply of indigenous labour prevented the fairly poor farmers from increasing production. The problem with this explanation is the modest use of slaves. Apparently, the settlers lacked the financial resources to employ any form of labour on a larger scale.

So, why was slavery introduced in an area that lacked potential buyers? Shell provides us with an answer to this paradox. The VOC initially brought slaves to the Cape for its own use and not in response to requests from the settlers. The VOC needed labour to develop Cape Town physically and administratively as the centre of the colony. In I770 I,000 slaves were employed by the VOC, a number ten times larger than the number of slaves employed by settler farmers. ${ }^{76}$ Enslaving the Khoisan was not an option because of Dutch law and due to the VOC's policy of avoiding major conflicts with the Khoisan. Slaves were not then introduced to solve the problems of labour shortages on settler farms. Indeed, there was no labour shortage on settler farms at that time. However, once slavery had been institutionalized as an urban phenomenon it could easily be expanded into rural areas when the agricultural economy began to grow in the eighteenth century.

\section{THE SLAVE ECONOMY}

It was not until the early I 700 s that agricultural production in general began to generate a surplus. ${ }^{77}$ Figure 4 reveals that the average number of slaves per settler farm increased steadily in the first half of the eighteenth century. It was by no means a coincidence that the use of slaves took off in this period. This correlates fairly well with the emergence and growth of a relatively wealthier group of settler farmers (the gentry), who took up viniculture and to some extent wheat farming. These farmers operated on larger landholdings with, on average, a larger number of slaves. ${ }^{78}$ The rise of the so-called Cape gentry thus played a decisive role in these developments, which gives us the necessary precondition for the NieboerDomar hypothesis to be valid: the intention and capacity to increase production. It also indicates that surplus and capital accumulation played a decisive role in the development of the slave economy.

The rise of the Cape gentry has been analysed by a number of scholars. Guelke and Shell, and Ross, were the first to discuss this group of wealthier farmers in relation to overall inequalities in the Cape. Ross

75. J.H. Coetzee, Verarming en Oorheersing (Cape Town, 1942), p. 41, cited in Fourie and Von Fintel, "Dynamics of Inequality", p. 236.

76. Shell, Children of Bondage, p. xxxi.

77. Ibid., pp. 234-236, 254.

78. Fourie and Von Fintel, "Dynamics of Inequality", p. 234. 


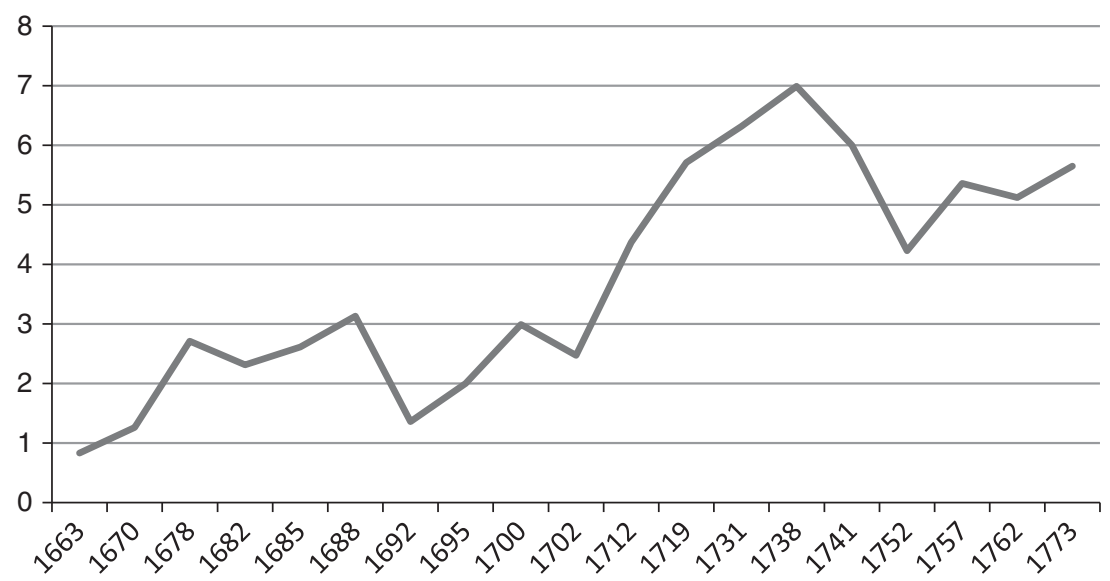

Figure 4. Mean of the total number of slaves per farm in the Cape, I663-1773.

Source: Johan Fourie and Dieter von Fintel, "The Fruit of Vine? An Augmented Endowments-Inequality Hypothesis and the Rise of an Elite in the Cape Colony", Working Paper I I2, UNU-WIDER (2010).

claims that the emergence of a gentry group should not be equated with the establishment of a white settler community per se, but

$[\ldots][r]$ ather the emergence of the gentry in any particular region of southern Africa can be dated to that moment when the class relations in the countryside were restructured so as to enable the production of cash crops on a fairly extensive scale under the immediate control of the landowner or his representative. ${ }^{79}$

Thus, it is proposed that the Cape gentry were a specific economic class that evolved as a consequence of new opportunities to benefit from economies of scale. We will return to this, but let us look first at what we know about the inequalities within the settler community in general and the rise of the Cape gentry in particular.

Guelke and Shell argue that the first three decades of the colony favoured small landholdings, but that the situation altered slowly between I705 and I73I as the cost of production rose, partly due to the state of the market, but also because the cost of land and labour almost doubled during that period. ${ }^{80}$ Guelke and Shell further claim that the process was marked by a concentration of land and capital as the marginal farmers unable to secure adequate labour were ousted by

79. Robert Ross, “The Rise of the Cape Gentry", Journal of Southern African Studies, 9 (1983), pp. 193-217, I93-194.

80. Guelke and Shell, “An Early Colonial Landed Gentry”, pp. $275^{-276 .}$ 


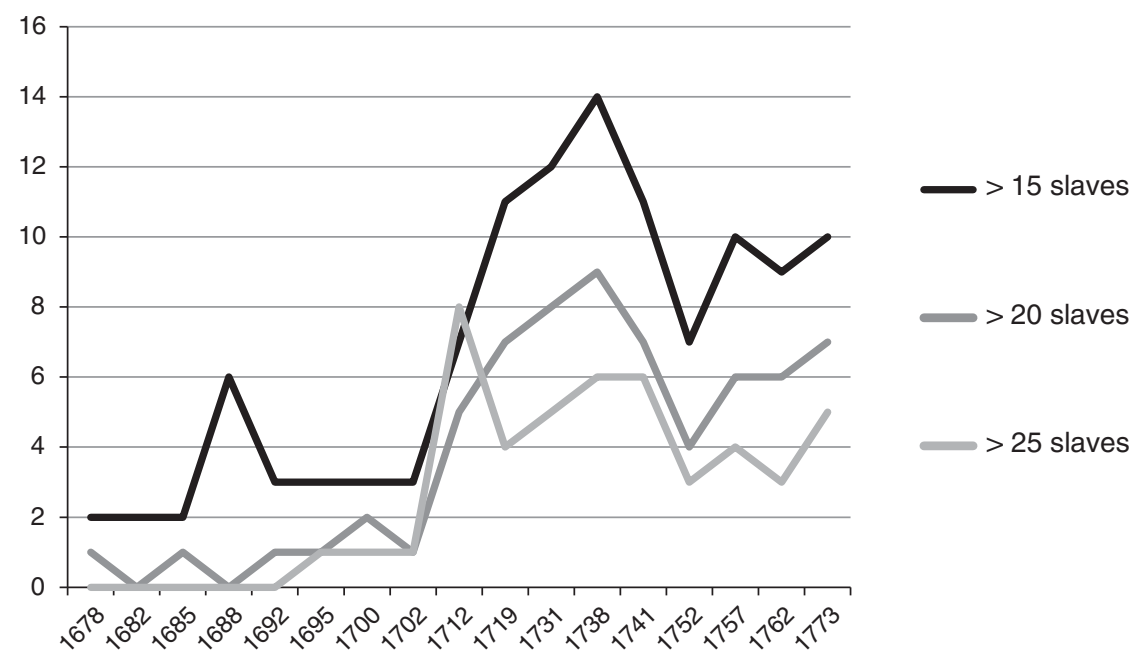

Figure 5. Share of white settlers with more than I5, 20, and 25 slaves in the Cape, 1663-1773. Source: Fourie and Von Fintel, "Fruit of Vine?", p. 20.

wealthier farmers. ${ }^{8 \mathrm{I}}$ In a more recent publication, Fourie and Von Fintel verify this view but provide a slightly different trajectory. Their quantitative assessment of asset-based inequality, based on inventories (opgaafrollen), suggests that the initially moderate levels of inequality increased in the first few decades of the colony, followed by a steady decline until 1738 , mainly because the poorest farmers became relatively wealthier. However, both Guelke and Shell and Fourie and Von Fintel conclude that by the I730s a new elite had emerged and that the Cape had developed into a society with high inequality levels. The Gini coefficient for the Cape in the mid-eighteenth century (including slaves) was above 0.70 , which indicates inequality levels equal to those of Spanish America. ${ }^{82}$

Although it is difficult to define the exact limits of the gentry by quantitative means alone, Fourie and Von Fintel provide useful indicators. They define the gentry in terms of the input of labour and the output of crops. Figure s shows clearly that the groups of relatively large slaveholders increased steadily from 1700 to 1730 . This was the period that marked the birth of the gentry. Comparing the importation of slaves (Figure 2), the mean number of slaves per farm (Figure 4), and the proportion of large slaveholders (Figure 5) also shows that the gentry grew in parallel with the establishment of the Cape as a slave society.

82. Fourie and Von Fintel, "Dynamics of Inequality", pp. $256-257$. 
While wealthier farmers expanded production, other farmers struggled to cope with high levels of debt. Guelke shows that from 1730 to 1740 the average level of debt for poorer farmers was equivalent to 78 per cent of the average gross assets of the estates. Guelke concludes that "While small cultivators found it increasingly difficult to secure a reasonable return on their invested capital, many of the large producers became exceptional wealthy." ${ }^{3}$

That the gentry played a decisive role in the emergence of slavery in the Cape is clear and indicates the significant role of capital and surplus production in the process. However, its role needs to be modified slightly. Fourie and Von Fintel's data (Figure 4) show that the group of largest slaveholders expanded up to I7I 2 but then declined. Ross shows that this trend continued in the latter half of the eighteenth century. In Drakenstein, the proportion of farmers who owned IO-I9 slaves increased from I 3.5 per cent in I73 I to 23.8 per cent in 1782 ; in Stellenbosch the corresponding figures were 16.9 per cent and 22.5 per cent respectively. Meanwhile, in Stellenbosch, as a proportion of all slave owners the largest slave owners (defined as farmers holding more than 20 slaves) decreased from I 8.5 to I 2.0 per cent during the same period, while Drakenstein saw a slight increase, from 4.9 to 7.8 per cent. ${ }^{8}$ The middling gentry, also known as the industrious farmers, played a decisive role in the transformation of the Cape into a slave society. They were able to exploit fully the benefits of slave labour by realizing economies of scale.

Yet, the supply of indigenous labour increased as well. As the settler community continued to expand, Europeans pushed even further into the interior in search of pasture. ${ }^{85}$ The expansion intensified in the first half of the eighteenth century and led to renewed conflicts between the settlers and the pastoral Khoisan communities. Previous research shows that by the early eighteenth century the expansion of the settler economy had reached the stage when no further growth was possible without indigenous societies disintegrating. ${ }^{86}$ Worden argues that the processes of primitive accumulation decreased the supply of indigenous labour, since the process of accumulation led to demographic collapse, which deepened with the outbreak of smallpox in I7I 3 that killed almost 90 per cent of the Khoisan population. ${ }^{87}$

83. Guelke, "White Settlers, $1652-1780$ ", p. 58.

84. Ross, "Rise of the Cape Gentry", p. 208.

85. Guelke, "Anatomy of a Colonial Settler Population", p. 456.

86. Worden, Slavery in Dutch South Africa; Nigel Penn, "Labour, Land and Livestock in the Western Cape during the Eighteenth Century", in W.G. James and M. Simons (eds), Class, Caste and Color: A Social and Economic History of the South African Western Cape (London, 1992), pp. 2-19; Guelke and Shell, "Landscape of Conquest".

87. Worden, Slavery in Dutch South Africa, p. 82. 
Naturally, all this had disastrous effects on the supply of labour, but how reliable is Worden's account? Ross shows convincingly that it is exaggerated. ${ }^{88} \mathrm{He}$ concludes that the smallpox outbreak in I7I 3 was unlikely to have killed more than 30 per cent of the Khoisan. ${ }^{89}$ The revised figure still, of course, had a devastating effect on Khoisan society and affected the overall supply of farm labour as well. Yet smallpox did not eradicate the indigenous labour force, and it seems plausible to assume that the consequence of primitive accumulation was an increase in the supply of local labourers. Penn refers to the period by "simply an account of the processes whereby the Khoi were stripped of their livestock and denied access to grazing and water resources - unless they were prepared to work for the colonists". ${ }^{\circ}$ The process of primitive accumulation took place roughly at the same time as slave imports began to take off, i.e. the supply of indigenous labour increased at the same time as the supply of slave labour. With the capacity to exploit land increasing, the settlers' demand for various forms of labour increased.

Our claim that Khoisan labour played an equally important role as farm labour is inconsistent with the fact that the use of Khoisan labour was never discussed as a practice or an alternative by the VOC during the eighteenth century. In 1717, after nearly two decades of growth, both in numbers and output, in the settler economy, the labour question was again on the VOC's agenda. In a response to Heeren XVII questions about labour in the Cape, the Cape Governor M.P. de Chavonnes and his council argued that slavery was preferable to European immigrant labour because of the high costs of controlling the latter. ${ }^{9 \mathrm{I}}$ Khoisan labour was not mentioned as an alternative, and this could be inferred as proof that indigenous labour was no longer available. That, however, is to take it one step too far. Indigenous labour continued to be employed, though the supply was not enough to meet the increased demand from the settlers. That is why an alternative was needed. Slavery did facilitate the expansion in the agrarian economy, but the majority of settlers continued to depend on a wide range of labour arrangements. In that sense, the widespread use of slaves depended on the existence of other forms of labour, and vice versa.

88. Since we lack data, Ross derives his figure by combining an in-depth understanding of the epidemiology of smallpox and an empirically detailed analysis of its effect on white settlers and slaves.

89. Robert Ross, "Smallpox at the Cape of Good Hope in the Eighteenth Century", African Historical Demography (1977), pp. 416-428.

90. Penn, "Labour, Land and Livestock", p. 4.

91. Nicole Ulrich, "Counter Power and Colonial Rule in the Eighteenth-Century Cape of Good Hope: Belongings and Protest of the Labouring Poor" (Ph.D., University of the Witwatersrand, Johannesburg, $201 \mathrm{I})$, p. 48. 


\section{SLAVERY AS CONTRACT LABOUR}

In the eighteenth century the Cape was a slave society, with its own specific and historically conditioned features. A distinctive feature of the Cape was the widespread use of slaves, but the average number of slaves per farm was low. Given this, it is easy to conclude that few farmers were able to exploit the full potential of slavery through economies of scale, while the majority were too poor to expand production. Contemporary witnesses support this view..$^{92}$ However, as we shall show, for large slave owners the profitability of using slaves is far from clear.

The VOC controlled the export markets and bought wheat and wine at fixed prices. That portion of any output that was not sold directly to the VOC was sold on the local market, although this practice was fairly uncommon due to the limited size of the domestic market. Figures $6 \mathrm{a}$ and $6 \mathrm{~b}$ reveal that the fixed prices for both wine and wheat remained more or less constant during the eighteenth century. At the same time, the price of slaves increased (Figure 7) and the slave population never managed to reproduce itself sufficiently to supply enough labourers to meet the needs of the expanding economy. ${ }^{93}$ This implies that the cost of production increased over time, which potentially threatened the sustained accumulation of capital. All this speaks against the use of slaves. Alternatively, to quote Worden, "[i]t would thus seem that Khoikhoi labourers were potentially an economically more viable labour force than that of slaves". 94

How can we explain the widespread use of slaves in a context in which it apparently made little economic sense, however? The easiest way, of course, is to claim that there were no alternatives, but that is not consistent with the scattered evidence we have. An alternative could be to argue, as Fourie and Von Fintel do, that not only economies of scale but also economies of scope mattered. ${ }^{95}$ Fourie has recently developed this argument further. He claims that slaves allowed farmers to specialize not only in agricultural products, but also in their by-products, such as tallow, skins, soap, and candles. According to Fourie, this protoindustrialization explains why farmers continued to invest in slaves despite the increase in the price of those slaves. ${ }^{96}$ We believe that the causality most likely moved in the opposite direction. The increased price of slaves forced farmers to increase the workload of slaves, by including less profitable activities such

92. Worden, Slavery in Dutch South Africa, p. 64.

93. Ibid., p. 63.

94. Ibid., p. 82.

95. Fourie and Von Fintel, "Dynamics of Inequality".

96. Johan Fourie, "Slaves as Capital Investment in the Dutch Cape Colony, I652-1795", in Ellen Hillbom and Patrick Svensson (eds), Agricultural Transformation in a Global History Perspective (London, 2013), pp. I36-1 59. 


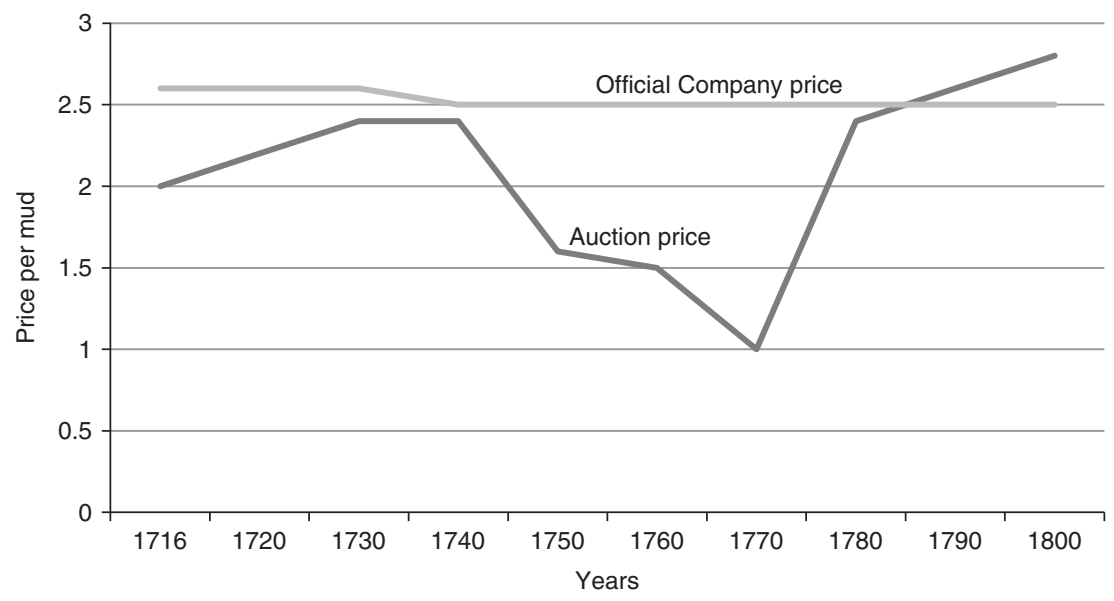

Figure 6a. Average price of wheat (per mud) 1716-1 800 (in Rixdollars).

Source: Worden, Slavery in Dutch South Africa, p. 69.

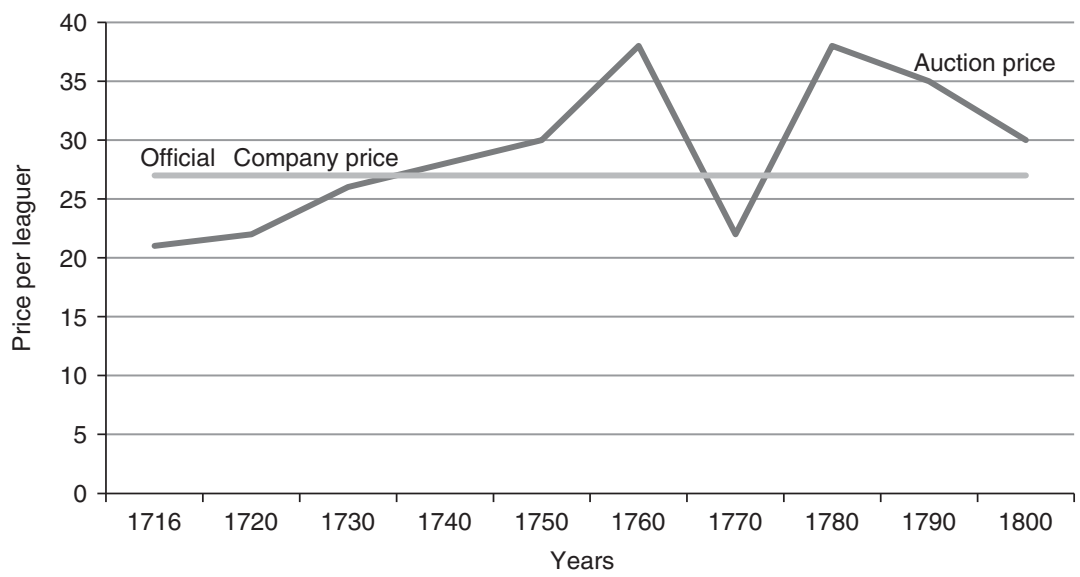

Figure 6b. Average price of white wine (per leaguer) 1716-1 800 (in Rixdollars).

Source: Worden, Slavery in Dutch South Africa, p. 69.

as candle-making, as a strategy to reduce the recurrent costs of keeping slaves. However, we agree with Fourie and Von Fintel that the use of slaves was profitable. In order to account for this, we need to widen our perspective and treat slavery as property used not only in production by the owner but also leased out on the market. It was possible to exploit these two functions of slaves because of the specific production processes in the south-western Cape. 


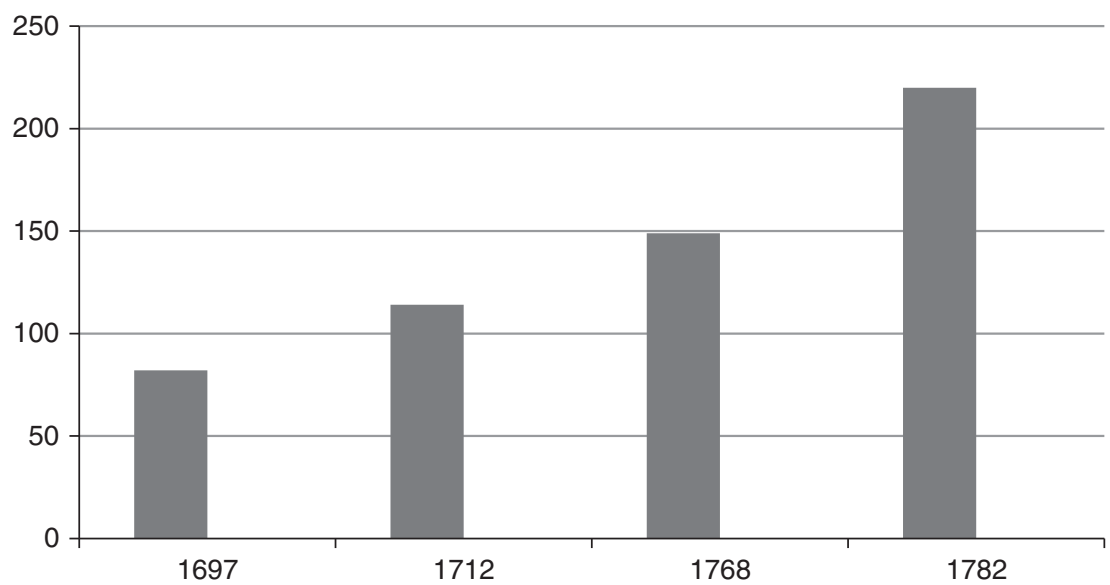

Figure 7. Average sale price in Rixdollars of adult male slaves in the Cape, selected years. Source: James C. Armstrong, "The Slaves, 1652-1795", in Elphick and Giliomee, Shaping of South African Society, pp. 75-I I5, 100.

As noted above, we follow Marx's basic assumption that the intervals in which labour is not used in the production process create neither value nor surplus value. Given this, there are incentives for farmers to enter flexible labour contracts that allow them to employ, release, and re-employ labourers on an annual basis. The dependence on weather conditions makes agriculture very vulnerable to delays in harvesting and sowing, meaning that farmers also had to be able to mobilize labour rapidly. The dilemma for the farmer was to be able to meet both demands, i.e. to develop systems that allowed for flexibility but that also ensured the right number of labourers could be put to work on a short-term basis.

The production of wheat in the Cape required a heavy input of labour during the sowing and ploughing seasons as well as during harvesting and threshing. Sowing and ploughing normally took place in May and July (where there were plenty of cattle, the land was prepared by manuring it in April). The ground was generally hard, and either hilly or clayish, and implied, according to Van Ryneveld in 1797 , that "the utensils imported, viz., spades, pickaxes, ploughs, ploughshares that are used in other countries, are not strong enough for, and of course no use to this Colony". ${ }^{97}$ Ploughing thus required concentrated, heavy field labour. The wheat was harvested from December to February and the work had to be performed relatively quickly to prevent strong south-easterly winds 
from flattening the fields of ripe corn..$^{8}$ During harvesting, work normally began at dawn and continued until about eight pm, with a short break in the afternoon. Equally, threshing demanded much labour and heavy work. At daybreak, the labourers spread the sheaves on the floor, which were then trampled by horses for a couple of hours, led by a number of labourers with short whips. In the afternoon the grain was separated from the straw by winnowing it with sieves. The straw was collected for fodder, while the grain was bound into sacks and loaded into wagons or stored in a barn on the farmstead. ${ }^{99}$

On wine farms there was a similar cycle of labour demand, though it was to some extent possible to coordinate it with wheat production, which enabled settler farmers to engage in mixed farming. Between July and September, i.e. after the ploughing and weeding season on the wheat farms, the vines had to be pruned and cut and the soil fertilized. Meanwhile, new vine stocks were planted in July and August. In October and November weeds were pulled up, stocks were propped, and the soil was hoed. These tasks, especially pruning, required a skilled workforce. During January and February labour demand was relatively low as the grapes were growing. The main task then was to keep birds and stray animals out of the vineyards. The peak season came immediately after the grain harvest. The grapes were picked and pressed for wine-making. Grape-picking began in late February and continued for about a month. The grapes were then pressed from September to November. ${ }^{100}$

The seasonal fluctuation in the demand for labour on wine farms was less substantial. In addition, workers could be kept busy from October to April, i.e. including the slack season (January-February), by digging the soil between the vines in order to aerate it and clear the undergrowth. ${ }^{\text {. I }}$ Both wine and wheat farming thus required a substantial amount of labour that could be mobilized at a fast rate for shorter periods during peak seasons. Slave labour could be mobilized easily, but it required the farmer to be able to afford to hold a large number of slaves throughout the year and for those slaves to be efficiently exploited during slack seasons. That the use of slaves was more common on wine farms comes as no surprise. The gap between work and production time was lower for wine compared with wheat, which simply meant that slaves could be more efficiently exploited.

Farmers who could not afford to buy and maintain a large number of slaves had to either reduce the gap between work and production time or

Iо I. Pamela Scully, The Bouquet of Freedom: Social and Economic Relations in the Stellenbosch District, South Africa, c.1870-1900 (Cape Town, 1990), p. 53. 
find alternative sources of labour. One way of reducing the gap was to engage in mixed farming, which allowed farmers to reallocate slave labourers between the wine and the wheat fields and thus keep the slaves busy throughout almost the entire agricultural season. It was possible to pursue this strategy because of the different timing of the gaps between wine and wheat farms. For the latter, the gap occurred roughly in August-December and again in March-July, while on wine farms the gap occurred in December and May-July. Previous research suggests that mixed farming was common, at least in the first half of the eighteenth century. Armstrong and Worden also claim that:

Although there were fluctuations, depending on the success of the annual crop as well as the accuracy of census recording, it is apparent that farmers producing both wine and grain had the closest correlations, and hence were the most efficient in exploiting their slaves largely because they made more intensive use of them throughout the year. ${ }^{102}$

By reducing the gap between work and production time, mixed farming enabled farmers to exploit the labour force more efficiently. However, this strategy was an option only for large landowners - the emerging class of "gentry" farmers - who could afford to hold a sufficient number of slaves. ${ }^{103}$ Worden's calculations support this, as he shows that the use of slaves was most profitable on large-scale and commercially oriented farms. ${ }^{104}$

A more suitable alternative for less wealthy farmers was to hire slave labour from large slave owners. This was a relatively efficient strategy to meet the gap between work and production time. We know little of how common this strategy was, though Mason suggests that it was utilized regularly, especially between wine and wheat farms. ${ }^{\text {105 }}$ Research on other slave societies too shows that the practice was common. Evans states with reference to slave hiring in Texas that "There is evidence to indicate that the hiring of slaves was a reasonably common characteristic of the slave system and the conditions of hire were generally quite standard." ${ }^{106}$ In German East Africa slave hiring had also become a common practice by the late nineteenth century. ${ }^{107}$

Contemporary witnesses from the Cape claim that it was quite profitable to lease slaves to other farmers, which indicates that supply

102. Quoted in Fourie and Von Fintel, "Dynamics of Inequality", p. 239.

103. Ibid.

104. Worden, Slavery in Dutch South Africa, p. 77.

I05. Mason, Social Death and Resurrection, p. I28.

106. Robert Evans, Jr, "The Economics of American Negro Slavery, I830-1860", NBER Working Paper (1962), pp. I85-256, I85.

107. Thaddeus Sunseri, "Slave Ransoming in German East Africa, I885-1922", International Journal of African Historical Studies, 26 (1993), pp. 48 I-5 I I. 
undercut demand. There was even an official recommended price for hiring slaves, indicating that the practice had become institutionalized in Cape society. In 1775 the rate was 4 Rixdollars per month plus food and tobacco. By 1783 the price had increased to 6 Rixdollars plus food and tobacco as an effect of the increasing price of purchasing slaves. Assuming a wealthy settler, holding more than 50 slaves, hired out 10 of his slaves for 3 months in 1775 , he would have received about $\mathrm{I} 20$ Rixdollars. The average price for an adult male slave in the same year was i95 Rixdollars, i.e. the income generated by hiring out 20 per cent of all his slaves was about 60 per cent of the price of a single slave. ${ }^{108}$

Theoretically, farmers holding fewer slaves who were forced to use them all in production during the busy season could hire out a significant number of slaves, given that the farmer specialized in either wine or wheat farming. A wheat farmer holding fifteen slaves could keep all his slaves busy during the peak season but hire out, for example, ten of them to wine farmers in May-June and December-February. Shell argues that the practice of hiring out slaves increased throughout the eighteenth century. He does not provide any evidence, but he does describe a very interesting case of a slave taking his contractor to court in 1704 over a wage dispute, a practice that suggests that the system of hiring out slaves was an institutionalized part of the Cape economy. ${ }^{\text {109 }}$

There is also evidence of slave owners hiring out slaves not only to other settlers, but also to the VOC. The archival records reveal a number of cases of settlers hiring slaves to the Landdrostdy on a permanent basis. For example, Jan Neal, a wine farmer from Stellenbosch, hired out two slaves from March 1730 to November 1737. In return, he was paid 225 Rixdollars, which is almost equivalent to what he would have earned by selling them at auction. ${ }^{10}$ Hiring out slaves was thus a relatively profitable enterprise, and although we lack estimates it seems that the practice had become institutionalized in Cape society.

The cost of hiring slaves was higher than the actual rent. The farmers had to provide the hired slaves with additional food and housing. However, for farmers who lacked the means to own a sufficient number of slaves, it is likely that, together with other forms of labour, the possibility of hiring slaves played a crucial role in their farming enterprises. The advantage of the system was that it lowered the transaction costs associated with hiring slaves on a contractual basis compared with the cost of day labourers. Less time had to be spent

108. Worden, Slavery in Dutch South Africa, pp. 72, 80.

109. Shell, Children of Bondage, p. Is.

I Iо. Ibid., p. 8I. 
on finding labourers with the right skills, and instead of "signing" a large number of contracts with each individual worker farmers had only to negotiate with the slave owner. The market developed because of the different production cycles of the two crops. It was the different production cycles for wheat and wine that enabled the establishment of a specific form of labour market and hence a specific form of labour relations, one that enabled large-, medium- and small-scale slave owners to benefit from slavery in a context that saw the relative price of slave labour increase.

\section{CONCLUSION}

The Nieboer-Domar hypothesis has featured in a significant body of scholarly work dealing with the economics of slavery in pre-colonial and colonial Africa. Most of the contributions deal with slavery in pre-colonial and colonial West Africa, but the role of slavery in the Cape Colony has also been analysed with the help of the Nieboer-Domar hypothesis. The present article sets out to achieve two things: first to reflect critically on the validity of the Nieboer-Domar hypothesis, and secondly to revise the perceived role of slavery in the Cape.

We have shown that the Nieboer-Domar hypothesis can be used in part to explain why slavery emerged in the Cape, but also that it needs to be modified. The supply of indigenous labour was initially low due to both land-labour ratios and the capacity of indigenous people to preserve their social organizations to some extent. However, the limited supply of labour was not, in fact, a major problem as the settler farmers lacked the means to employ any form of labour on a larger scale. It was the VOC's demand for labour that led to slaves being imported to the Cape. With the expansion of the settler community in the eighteenth century, a new group of relatively wealthy farmers emerged that demanded more labour. Slavery, which already existed as an institution in urban areas, became one of the major forms of labour employed by these farmers. However, the use of slaves increased in parallel with the use of other forms of labour, i.e. the rise, role, and profitability of slave labour can be understood only in relation to the various forms of labour contract used on settler farms.

We have shown that in the case of the Cape a historically accurate understanding of different forms of labour requires production systems and production processes to be included in any analysis. It is impossible to separate systems of allocation from systems of production. The supply of labour does not matter if it is unrelated to demand, and vice versa. The demand for various forms of labour depends on the possibility to generate a surplus, but also on the type of production, the available technologies, and the degree of control over the factors of production. In this article we suggest that Marx's argument, that the larger the gap 
between work and production time the less surplus value is created, provides us with a useful entry point to structure our understanding of the production systems specific to the Cape. It explains the different roles of slavery in relation to coexisting forms of labour, and so helps us to understand why slavery was maintained.

From a purely theoretical perspective, our case shows that one cannot detect the dynamics of economic change by looking at relative scarcity only. Supply and demand matter, but how they matter is conditioned historically, i.e. the study of history requires explanatory models that allow history and historical forces to play a part. The Nieboer-Domar hypothesis is a powerful tool that helps us to identify part of the context, but its explanatory powers depend on how well it travels with less universal and more historically oriented assumptions of economic change.

\author{
TRANSLATED ABSTRACTS \\ FRENCH - GERMAN - SPANISH
}

Erik Green. L'économie de l'esclavage au dix-buitième siècle. En révisant l'hypothèse de Nieboer-Domar

L'hypothèse de Nieboer-Domar s'est avérée être un puissant instrument pour identifier les conditions économiques dans lesquelles l'esclavage devient plus probablement une forme prédominante de main-d'œuvre. L'hypothèse soutient que dans les cas d'abondance de sols et de pénuries de main-d'œuvre, l'utilisation de l'esclavage devint plus vraisemblablement une alternative indispensable pour augmenter la production. Ces conditions furent identifiées pour de grands pans de l'Afrique précoloniale et en partie pour l'Afrique coloniale. L'hypothèse NieboerDomar fut utilisée par plusieurs historiens et historiens de l'économie pour analyser le rõle de l'esclavage et du travail forcé en Afrique. L'hypothèse ne resta cependant pas incontestée. Les chercheurs la critiquèrent pour des raisons tant théoriques qu'empiriques. Cet article discute la validité de l'hypothèse de NieboerDomar, en prenant pour point de départ la Colonie du Cap au dix-huitième siècle. Nous montrons que l'hypothèse se vérifie dans une certaine mesure, mais qu'il convient de la modifier. Premièrement, l'esclavage naquit en tant que phénomène urbain. Deuxièmement, l'utilisation d'esclaves augmenta parallèlement à d'autres formes de main-d'œuvre, et le rôle des esclaves ne peut être compris qu'en relation avec un grand nombre de contrats de travail existants. Lorsqu'il fut bien implanté, l'esclavage joua un rôle important pour faciliter un accroissement de la production sur les exploitations agricoles des colons au dix-huitième siècle. La capacité de production excédentaire fut l'élément déterminant, mais la raison pour laquelle les esclaves devinrent une importante forme de main-d'œuvre fut en partie la conséquence de l'existence préalable de l'esclavage dans les zones urbaines, et en partie de la manière dont il se combina avec d'autres formes de main-d'œuvre

Traduction: Christine Krätke-Plard 
Erik Green. Die Ökonomie der Sklaverei in der Kapkolonie des I8. Jahrbunderts: Eine Überprüfung der Nieboer-Domar-These

Die Nieboer-Domar-These hat sich als wirkungsvolles Instrument erwiesen, um die wirtschaftlichen Bedingungen zu bestimmen, unter denen es besonders wahrscheinlich ist, dass die Sklaverei zum vorherrschenden Arbeitsverhältnis wird. Ihr zufolge war die Wahrscheinlichkeit, dass die Sklaverei zum ausschlaggebenden Mittel der Produktionssteigerung werden würde, dann besonders hoch, wenn viel Land aber nur wenige Arbeitskräfte zur Verfügung standen. Solche Bedingungen haben sich für weite Gebiete des vorkolonialen Afrikas, teilweise aber auch für das koloniale Afrika nachweisen lassen. Mehrere Historiker und Wirtschaftshistoriker haben von der Nieboer-Domar-These Gebrauch gemacht, um die Rolle der Sklaverei und der Schuldknechtschaft in Afrika zu analysieren. Die These ist jedoch nicht unangefochten geblieben. Forscher haben sie sowohl theoretisch als auch empirisch kritisiert. Der Aufsatz diskutiert die Triftigkeit der Nieboer-DomarThese und geht dabei von der Kapkolonie des I8. Jahrhunderts aus. Er zeigt, dass die These zwar teilweise zutrifft, jedoch modifiziert werden muss. Erstens entwickelte sich die Sklaverei als städtisches Phänomen. Zweitens dehnte sich die Sklaverei parallel zu anderen Arbeitsformen aus, und die Rolle der Sklaven lässt sich nur begreifen, wenn sie zu einem breiten Spektrum bereits bestehender Arbeitsverträge in Beziehung gesetzt wird. Sobald sie sich durchgesetzt hatte, begann die Sklaverei eine wichtige Rolle bei der Erleichterung von Produktionssteigerungen auf den Siedlerhöfen des I8. Jahrhunderts zu spielen. Kapazitäten der Überschussproduktion waren der Hauptfaktor. Dass aber die Sklaverei eine der wichtigsten Arbeitsformen wurde, war teilweise Folge ihres vorherigen Vorhandenseins in den städtischen Gebieten, und teilweise Folge ihrer Kombinierbarkeit mit anderen Arbeitsformen.

Übersetzung: Max Henninger

Erik Green. La economía de la esclavitud en Ciudad del Cabo en el siglo XVIII. Revisando la hipótesis Nieboer-Domar

La formulación de la hipótesis Nieboer-Domars ha demostrado ser una herramienta muy influyente a la hora de identificar las condiciones económicas bajo las que resulta más probable que emerja la esclavitud como forma de trabajo dominante. Esta establece que en casos de abundancia de tierras y de escasez de mano de obra existía una mayor probabilidad de que el uso de la esclavitud llegara a ser una alternativa esencial para conseguir un incremento de la producción. Estas condiciones se han identificado en grandes partes del Africa precolonial y, aunque parcialmente, también del Africa de la época colonial. La hipótesis Nieboer-Domar ha sido utilizada por un gran número de historiadores e historiadores económicos a la hora de analizar el papel de la esclavitud y del trabajo forzado en Africa. La hipótesis, sin embargo, no ha quedado sin contestación. Algunos académicos han criticado su planteamiento tanto desde la perspectiva teórica como desde el campo empírico. En este artículo debatimos la validez de la hipótesis Nieboer-Domar tomando como punto de partida para su aplicación el ejemplo de la colonia de 
Ciudad del Cabo a lo largo del siglo XVIII. Con ello evidenciamos que la hipótesis se sostiene, pero tan sólo en parte, y necesita alguna que otra modificación. En primer lugar, señalamos que la esclavitud emergió como un fenómeno urbano. En segundo lugar, constatamos que el uso de esclavos se incrementó de forma paralela a la extensión de otras formas de trabajo y que el rol de los esclavos sólo puede ser comprendido si lo ponemos en relación con el panorama mucho más amplio de fórmulas laborales existentes. Una vez la esclavitud quedó establecida vino a jugar un papel de importancia en la consecución de incrementos de la producción en las granjas de los colonos a lo largo del siglo XVIII. La capacidad de generar un excedente de producción se convirtió en el factor clave, pero el hecho de que los esclavos llegaran a ser una forma de trabajo relevante fue debido, en parte, como consecuencia de su pre-existencia en las áreas urbanas y, en parte, como consecuencia de la combinación de esa esclavitud con otras formas de trabajo.

Traducción: Vicent Sanz Rozalén 